Research Article

\title{
Comparison of Presplit and Smooth Blasting Methods for Excavation of Rock Wells
}

\author{
Zilong Zhou $\mathbb{D}^{\mathrm{D}},{ }^{1}$ Ruishan Cheng $\mathbb{D}^{1},{ }^{1}$ Xin Cai $\mathbb{D}^{1},{ }^{1}$ Jinlong Jia, $^{2}$ and Weihua Wang ${ }^{1}$ \\ ${ }^{1}$ School of Resources and Safety Engineering, Central South University, Changsha 410000, China \\ ${ }^{2}$ Chuangyi Blast Project Limited Company of Hunan, Changsha 410000, China \\ Correspondence should be addressed to Ruishan Cheng; chengruishan@csu.edu.cn and Xin Cai; xincai@csu.edu.cn
}

Received 20 January 2019; Revised 2 April 2019; Accepted 7 April 2019; Published 23 April 2019

Academic Editor: Roger Serra

Copyright (c) 2019 Zilong Zhou et al. This is an open access article distributed under the Creative Commons Attribution License, which permits unrestricted use, distribution, and reproduction in any medium, provided the original work is properly cited.

To understand differences of smooth and presplit blasting for the excavation of rock wells, two field experiments using these two techniques are implemented at the same test site, respectively. The ground vibrations induced by them have been monitored with the different distances through the corresponding devices. The vibration results illustrate that at the same monitoring distance and direction, peak particle velocities and dominant frequencies of vibration signals based on presplit blasting are both apparently lower than that based on smooth blasting. Meanwhile, with the increase of distance, the principle and mean frequencies based on smooth blasting always decrease, but these two frequencies based on presplit blasting might firstly decrease and then rise. In addition, frequency bands of energy distributions based on smooth blasting are more dispersive than that based on the presplit blasting at the same distance and direction. Lastly, the excavation qualities of rock wells with two techniques are also measured. The excavation results demonstrate that the contour quality and flatness of well bottom based on smooth blasting are better than that based on presplit blasting. Nevertheless, well depth based on presplit blasting is larger than that based on smooth blasting.

\section{Introduction}

Drilling and blasting methods have been extensively applied to rock excavation in mining and civil engineering due to its low cost, high efficiency, and easy operation. [1-5]. However, some inevitable negative effects are often encountered under the blasting loads, such as blast-induced damage and vibration [6-10]. To minimize and reduce these problems, presplit and smooth blasting as the advanced control techniques have been widely introduced into blasting design [11-13]. In the blast design of rock wells or tunnels, presplit and smooth blasting both need to drill a circle of small spacing boreholes along the designed contour line [14], as shown in Figure 1(a). These boreholes are usually the same diameter as the main boreholes. All peripheral holes are lightly loaded and decoupled with low-powered explosives. The primary difference between presplit and smooth blasting is the firing sequence of contour holes relative to the main blasting area [15]. As shown in Figure 1(b), the peripheral holes based on smooth blasting are detonated after main boreholes. On the contrary, the peripheral holes based on presplit blasting are detonated prior to main boreholes.

Over the past decades, some significant surveys on smooth and presplit blasting have been conducted by many researchers. Zare and Bruland [16] discussed the influence of smooth blasting on two tunnel blast design model. The results indicated the good excavation qualities could be both achieved by the two design models with the smooth blasting. Mandal et al. [17] put forward a mathematical model for smooth blasting pattern and then it was applied to form the high quality pit wall. Chen et al. employed the deep-hole presplit blasting to separate hard roof and coal body. The results illustrated the working resistance of supports was significantly reduced after the presplit blasting. Ma et al [18] explored the vibration absorption effect of presplit blasting in an open cast mine. The results showed that presplit blasting can reduce the attenuation coefficient of stress wave obviously. Li et al. [19] conducted the numerical investigation for the smooth blasting in rock excavation based on timing sequence and noncoupling charge. The results 


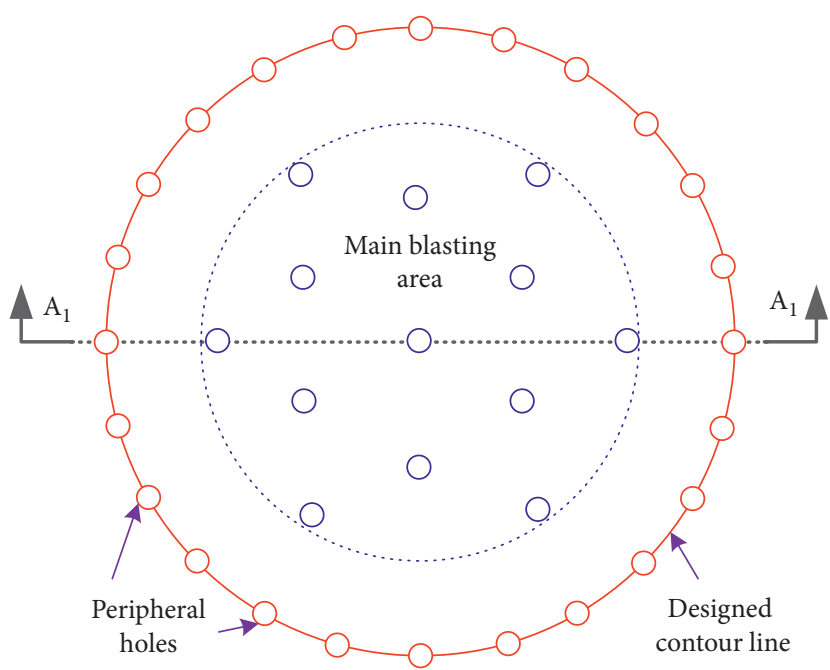

(a)

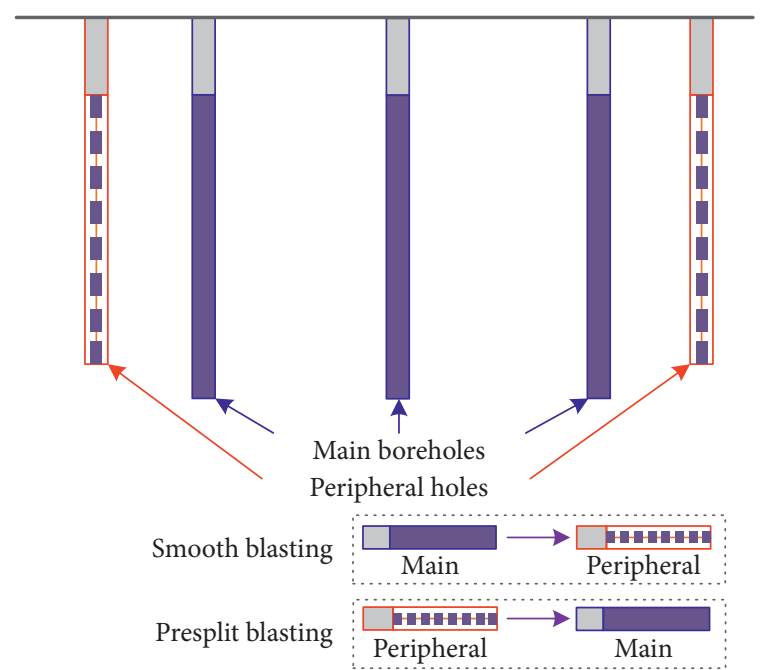

(b)

Figure 1: Hole arrangement and sequence of two control methods. (a) Excavation of rock well. (b) $A_{1}-A_{1}$ section.

showed that sidewall cracks could be formed with low depth of rock damage by this smooth technique. Liu and Liu [20] proposed a new model to optimize the smooth blasting parameters for mountain tunnel construction based on the genetic algorithm (GA) and improved support vector regression coupling algorithm (ISVR). The results revealed that the proposed model could obtain the feasible and reliable parameters for smooth blasting.

According to the previous investigations, workers come to realize that although the two control techniques could both effectively restrain blast-related problems in most cases, their excavation effects are quite distinct due to different firing sequences. In order to explore differences of presplit and smooth blasting, the comparisons of the two control techniques have been conducted by some scholars from several perspectives. Lu et al. [21] compared the difference of presplit and smooth blasting from the difficulty of crack forming during the excavation of underground tunnel. The results indicated that when the in situ stress was higher than 10-12 MPa, the contour cracks were not well formed by presplit blasting. Hu et al. [22] investigated the blast-induced rock damage process with presplit and smooth blasting techniques during the excavation of high rock slope. The results demonstrated that when smooth blasting was applied, the damage zones were induced by the explosives of all boreholes, but when presplit blasting was used, damage zones were only induced by the explosives of peripheral boreholes. Hu et al. [23] also analyzed the flatness of excavation surface produced by smooth and presplit blasting. The results showed the flatness based on smooth blasting was better than that based on presplit blasting at the side excavation surface.

Through the above analysis, it can be found that those comparison factors like crack, flatness, and damage are all related to excavation quality, whose influences are limited to the vicinity of the explosive source. Nevertheless, in practice, residents in the neighborhood are more concerned about the adverse impacts of blast-induced vibrations because they can propagate over long distances [24-27]. Hence, it is vital to investigate the vibration characteristics induced by blasting operations with two control techniques. However, to date, there is still a lack of report that exposes differences of two control techniques from the effects of blasting vibrations.

In this study, to synthetically reveal the differences of presplit and smooth blasting, blast-induced vibrations and excavation qualities of rock wells based on two control techniques are investigated. Firstly, two field experiments for the excavation of rock wells using presplit and smooth techniques are carried out at the same test site, respectively. Subsequently, vibration characteristics induced by two field experiments are analyzed depending on the PPV, frequency, and energy. Lastly, the well-forming results based on two control techniques are compared from well flatness and depth.

\section{Field Experiments for the Excavation of Rock Wells}

2.1. Experiment Site. The site of two experiments is located at Zixing city of Hunan Province in China, as shown in Figure 2. Based on the geological information received from the test site, the main host rock at the test area is hard limestone with good mass quality. Block samples and rock cores both are collected from the experiment area for geomechanical testing in the laboratory. Their physical and mechanical parameters are shown in Table 1.

2.2. Implementation of the Field Experiments. In the two experiments, the expected diameters of rock wells both are $2.5 \mathrm{~m}$. As shown in Figure 3, five main boreholes and four empty holes are arranged inside the well boundary. Meanwhile, there are twelve peripheral boreholes assigned uniformly at the contour of rock wells. The boreholes and empty holes are drilled by $100 \mathrm{~mm}$ and $250 \mathrm{~mm}$ borings, respectively. The spacing between empty and main boreholes 


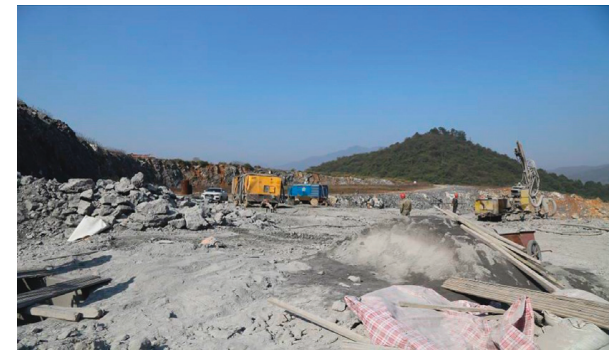

Figure 2: The field experiment site.

TABle 1: Physical and mechanical parameters of rock.

\begin{tabular}{lc}
\hline Parameter & Value \\
\hline Mass density $\rho\left(\mathrm{kg} / \mathrm{m}^{3}\right)$ & 2518 \\
Elastic modulus $E_{0}(\mathrm{GPa})$ & 25.63 \\
Shear modulus $E_{\text {tan }}(\mathrm{GPa})$ & 13.27 \\
Compressive strength $\sigma_{\mathrm{c}}(\mathrm{MPa})$ & 93 \\
Tensile strength $\sigma_{\mathrm{t}}(\mathrm{MPa})$ & 12.5 \\
Poisson ratio $\mu$ & 0.28
\end{tabular}

is set to $600 \mathrm{~mm}$. The drilled depths of main, empty, and peripheral holes are $7.5 \mathrm{~m}, 5 \mathrm{~m}$, and $6.5 \mathrm{~m}$, respectively.

After the abovementioned boreholes and empty holes are drilled, the charge and stemming of boreholes need to be conducted. Here the 2\# rock emulsion explosive is used for main and peripheral holes. The peripheral holes use decoupling charges, and its decoupling coefficient is 1.5625 . The coupling charges are applied to main holes. The charge weights of each peripheral and main boreholes are $4.5 \mathrm{~kg}$ and $18 \mathrm{~kg}$, respectively. Consequently, the linear charge densities of main and peripheral holes are $2.40 \mathrm{~kg} / \mathrm{m}$ and $0.69 \mathrm{~kg} / \mathrm{m}$, respectively. The explosive consumption is $4.56 \mathrm{~kg} / \mathrm{m}^{3}$. To guarantee the reliability of detonation, two millisecond delay detonators with same delay times and one detonating cord as long as hole charge are arranged on each borehole. These two detonators in each hole are fixed at the top and bottom of charge, respectively.

When presplit blasting is applied to the excavation of rock well, the delay times for peripheral and main boreholes are $0 \mathrm{~ms}$ and $110 \mathrm{~ms}$, respectively. When smooth blasting is applied to excavation of rock well, the delay times for peripheral and main boreholes are $110 \mathrm{~ms}$ and $0 \mathrm{~ms}$, respectively. To monitor the ground vibrations, three vibration instruments (TC-4580) are also installed with $30 \mathrm{~m}, 50 \mathrm{~m}$, and $150 \mathrm{~m}$ source distances for every field experiment.

\section{Field Experiment Results}

3.1. Vibration Induced by Excavation of Rock Wells. After the two experiments are conducted, the vibration signals generated by them have been monitored and are shown in Figure 4. Although it can be seen that the PPVs in radial and tangential directions both occur within the detonation duration of main boreholes for two techniques, the vibration waveforms of two experiments are obviously different. To explore the difference of vibration characteristics induced by two techniques, the PPV, frequency, and energy of vibration signals are further analyzed in the following sections.
3.1.1. PPV Characteristics. According to the vibration signals of three monitoring sites, PPVs from main and peripheral boreholes in radial and tangential directions based on smooth and presplit blasting are depicted in Figure 5. It can be seen that the PPVs from main and peripheral boreholes in two directions all decrease gradually and nonlinearly with the increases of monitoring distances, whether presplit blasting or smooth blasting. Meanwhile, the PPVs from main boreholes based on presplit blasting are smaller than that based on smooth blasting at the same distance and direction. The reason is that when presplit blasting is applied, the peripheral boreholes are detonated prior to main boreholes, which results in that the stress waves produced by main boreholes reflect and attenuate around well boundary. Moreover, the gaps of PPVs from main boreholes between smooth and presplit blasting enlarge gradually in the radial direction with the increases of distances. However, the gaps of PPVs from main boreholes between smooth and presplit blasting decrease gradually in tangential direction with the increases of distances. For PPVs from peripheral boreholes, although the PPVs in the radial direction based on smooth blasting are larger than that based on presplit blasting at the same distance, PPVs in the tangential direction based on smooth blasting are smaller than that based on presplit blasting.

3.1.2. Frequency Characteristics. In addition to PPV, the frequency is another evaluation indicator of the vibration signals [28]. Figure 6 presents the frequency spectra of vibration signals induced by the two experiments with different contour techniques. It can be seen that with the increases of monitoring distances, high-frequency components of vibration signals from main and peripheral boreholes all decrease based on two control techniques in the same direction. For instance, when the monitoring distances increase from $30 \mathrm{~m}$ to $50 \mathrm{~m}$ in the radial direction, the highfrequency components attenuate obviously, and the lowfrequency components slightly decrease. Moreover, at the same monitoring distances, the ranges of frequency bands based on the smooth blasting are wider than those based on the presplit blasting, whether main or peripheral boreholes. For example, when the monitoring distance is $30 \mathrm{~m}$, frequency bands for main boreholes based on smooth blasting are within $150 \mathrm{~Hz}$ in the tangential direction (see the right picture of Figure 6(a)), but frequency bands from main boreholes based on presplit blasting are within $100 \mathrm{~Hz}$ in the tangential direction. Meanwhile, the domain frequencies (corresponding to the square root of the second moment of the Fourier spectrum) for main and peripheral boreholes based on smooth blasting are larger than those based on the presplit blasting at the same monitoring distance and direction. For example, when the monitoring distance is $50 \mathrm{~m}$, the dominant frequency from peripheral boreholes in the tangential direction based on presplit blasting is $20 \mathrm{~Hz}$ (see the right picture of Figure 6(b)), but the dominant frequency from peripheral boreholes in the tangential direction based on smooth blasting is $52 \mathrm{~Hz}$. For the presplit blasting, the frequency components of main boreholes are influenced by 


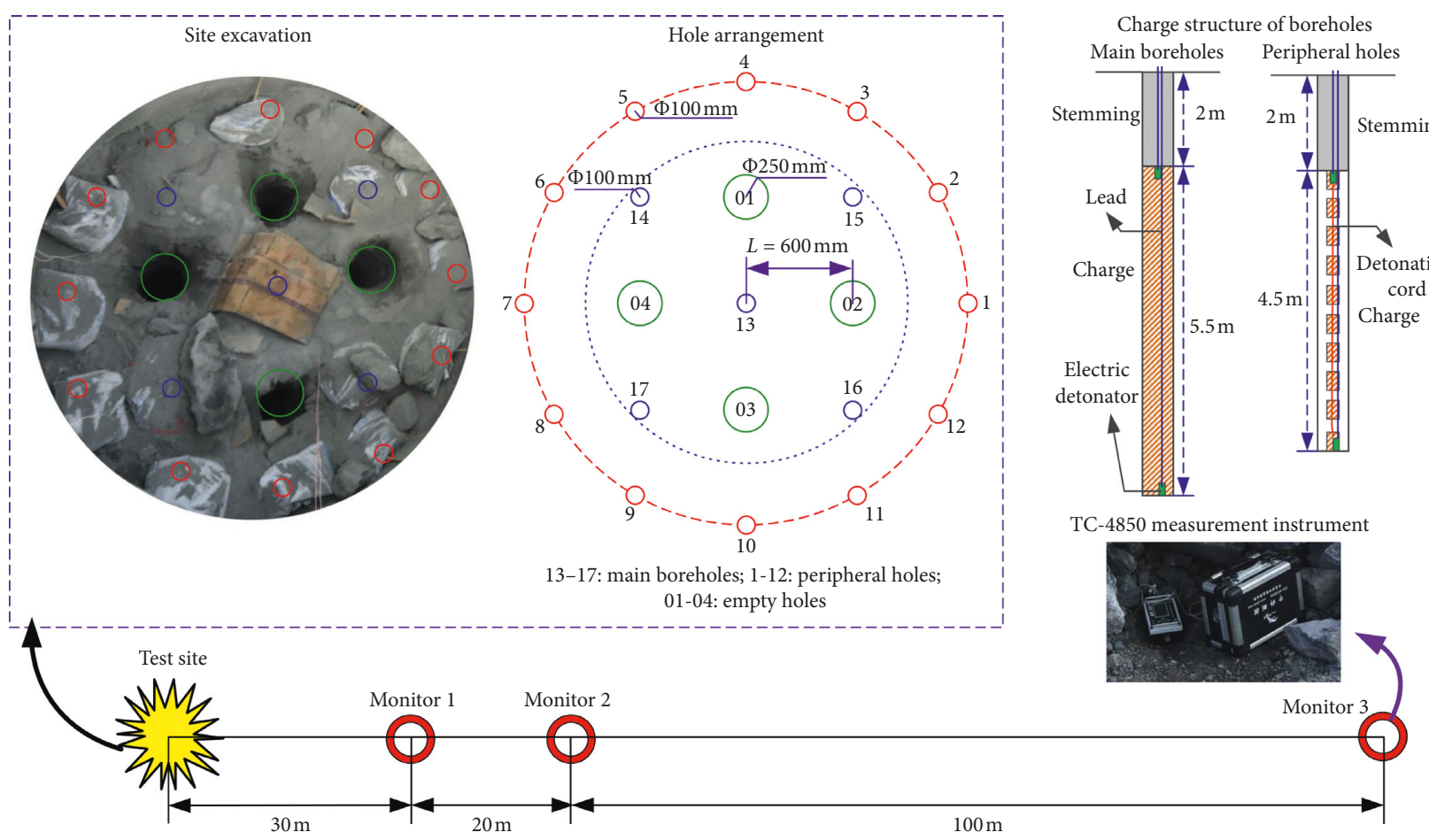

Figure 3: Schemes of blast implementation and vibration measurement for two field experiments.
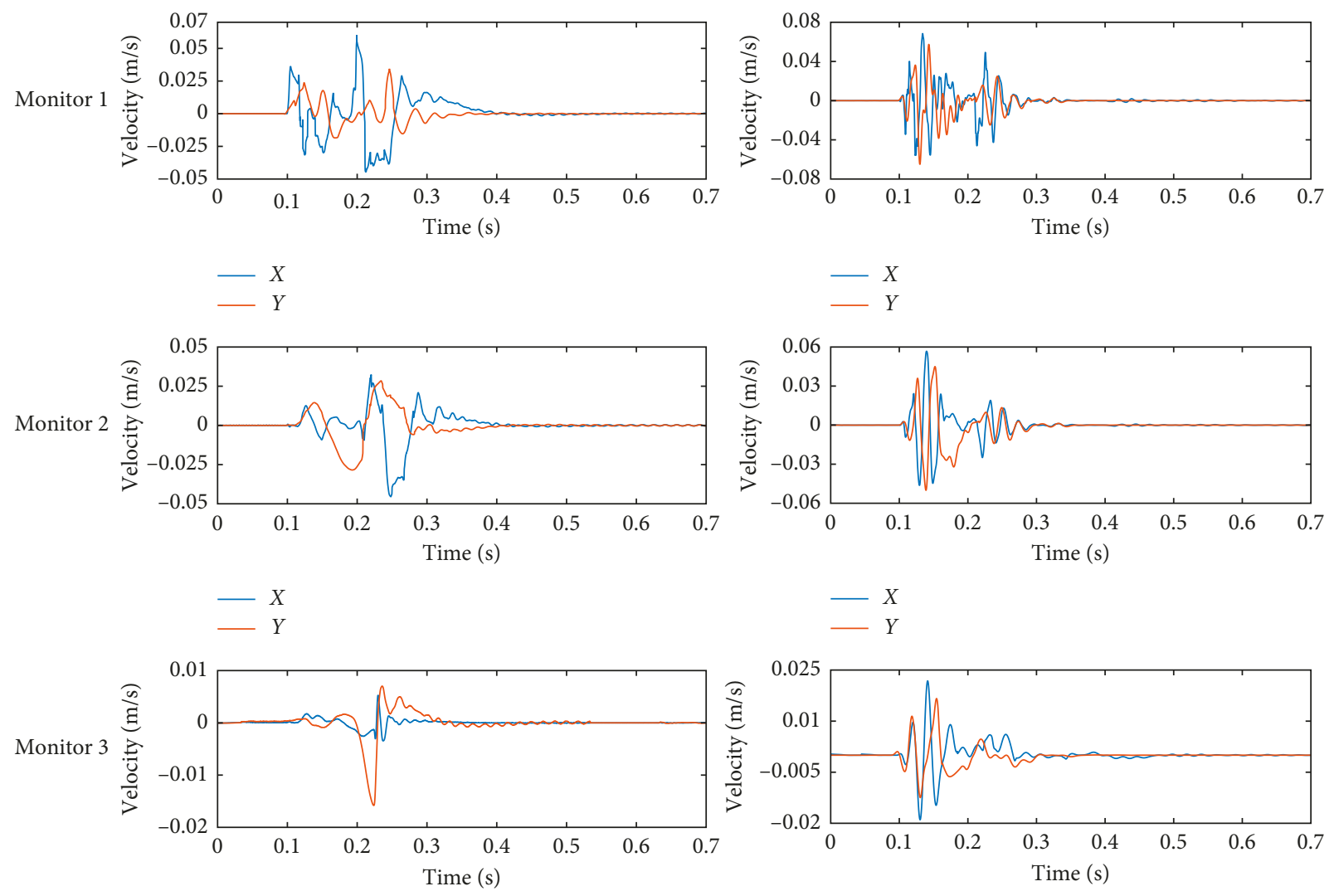

$$
\begin{array}{r}
X \\
-Y
\end{array}
$$$$
-X
$$

(a)

(b)

FIgURE 4: The vibration signals induced by the excavation of rock wells with (a) presplit blasting and (b) smooth blasting. $X$ and $Y$ represent radial and tangential directions, respectively. 


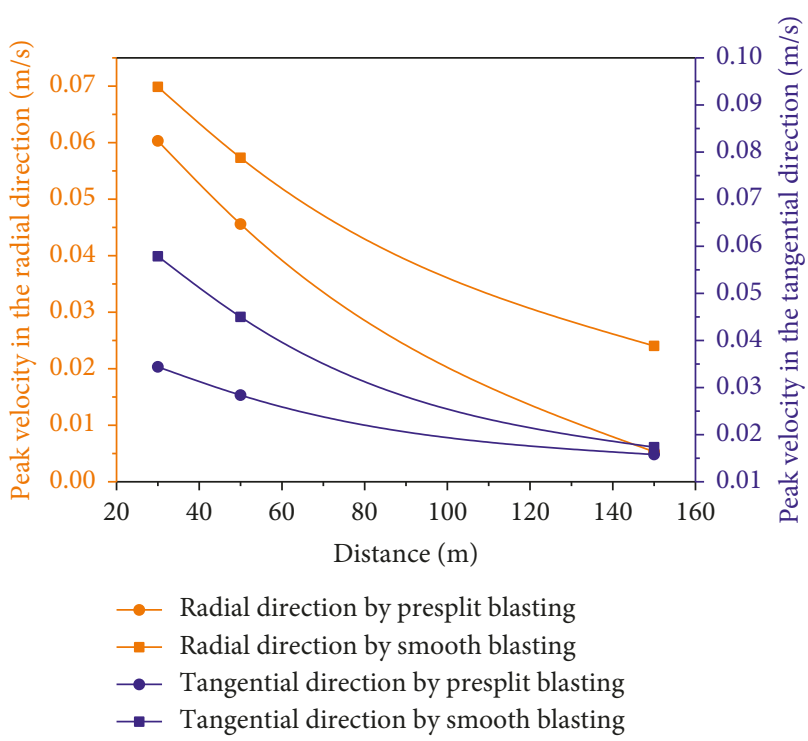

(a)

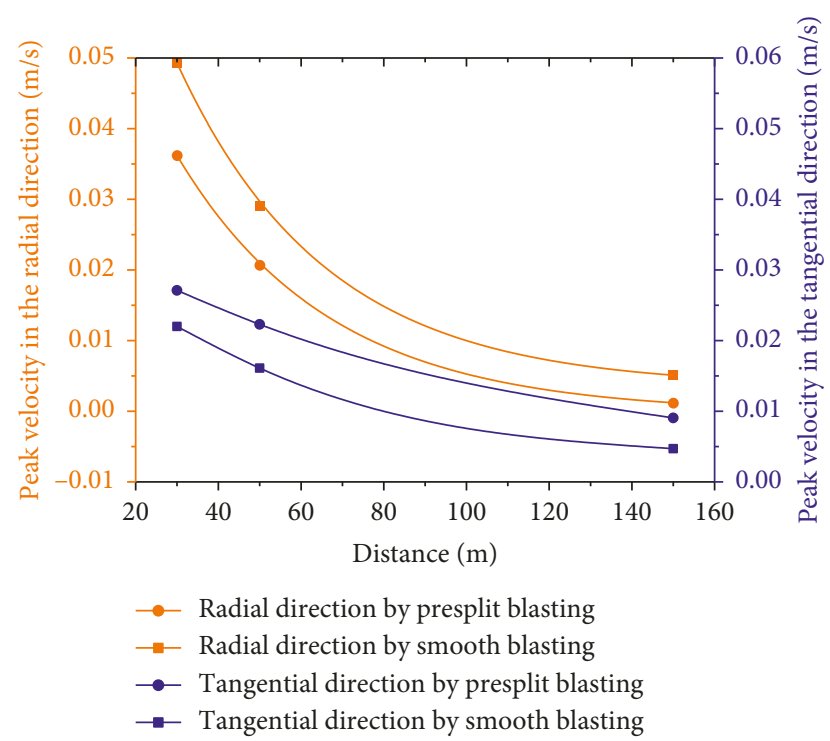

(b)

FIgURE 5: The variations of PPVs from (a) main and (b) peripheral boreholes versus distances in radius and tangential directions based on smooth and presplit blasting.

pregenerated contour cracks under the action of peripheral boreholes, which makes the dominant frequency of main boreholes with presplit blasting smaller than that with smooth blasting at the same distance and direction. For the smooth blasting, the frequency components of peripheral boreholes are influenced by the inner free face generated by main boreholes, which makes the dominant frequency of peripheral boreholes with smooth blasting larger than that with presplit blasting at the same distance and direction.

Besides the dominant frequency, principal frequency $(\mathrm{PF})$ and the mean frequency (MF) are another two analysis indicators of frequency characteristics. PF is generally determined by half of the maximum spectral peak in the Fourier spectrum (see Figure 7), and it is defined by $\mathrm{Wu}$ et al. [29] as follows:

$$
\mathrm{PF}=\frac{F_{1}+F_{2}}{2},
$$

where $F_{1}$ and $F_{2}$ are determined by drawing a horizontal line at half of the maximum peak in the Fourier spectrum. Meanwhile, the MF can be obtained from Yang et al. [30]:

$$
\mathrm{MF}=\frac{\sum_{i=1}^{m} F_{i} f_{i}}{\sum_{i=1}^{m} F_{i}},
$$

where $F_{i}$ is the amplitude corresponding to the frequency $f_{i}$ in the Fourier spectrum.

By equations (1) and (2), PF and MF of vibration signals induced by the two field experiments are obtained. Their results have been manifested in Figures 8 and 9, respectively. From Figure 8, it can be seen that PF based on the smooth blasting is always larger than that based on presplit blasting at the same distance and direction, whether main or peripheral boreholes. In addition, PF from both main and peripheral boreholes based on smooth blasting decreases gradually with the increases of distances, but PF from main boreholes based on presplit blasting firstly decreases and then rises with the increases of distances. Meanwhile, in the tangential direction, PF from peripheral boreholes based on presplit blasting also firstly decreases and then rises with the increases of distances. This phenomenon is mainly due to that various frequency components of vibration signals attenuate with different decay rates. Within a certain distance, the higher frequency components attenuate more quickly than lower frequency components, resulting in the reduction of PF. However, when the certain distance is exceeded, the lower frequency components also decay rapidly, which makes PF rise again. From Figure 9, it can be found that the MF based on smooth blasting both cut down with the increases of distances in the radial and tangential directions. However, for presplit blasting, MF from main boreholes in the radial direction and MF from peripheral boreholes in the tangential direction firstly decrease and then go up with the increases of distances. This phenomenon is similar to the above PF situation.

3.1.3. Energy Characteristics. Although the PPV and frequency can expose the transient characteristics of vibration signals, the energy effects of vibration signals are still neglected. In order to comprehensively assess the blastinduced vibrations, the wavelet packet method [31] is applied to obtain energy characteristics of vibration signals. By the wavelet packet method, the signal series $h(t)$ can be decomposed into $2^{i}$ subbands in the $i^{\text {th }}$ decomposition level. The original signal series $h(t)$ can be expressed as follows:

$$
h(t)=\sum_{j=0}^{2^{i}} f_{i, j}\left(t_{j}\right)=f_{i, 0}\left(t_{0}\right)+f_{i, 1}\left(t_{1}\right)+\cdots+f_{i, 2^{i}-1}\left(t_{2^{i}-1}\right),
$$

where $f_{i, j}\left(t_{j}\right)$ is the reconstructed signal of the $j^{\text {th }}$ frequency band in $i^{\text {th }}$ level. If the upper frequency limit of 

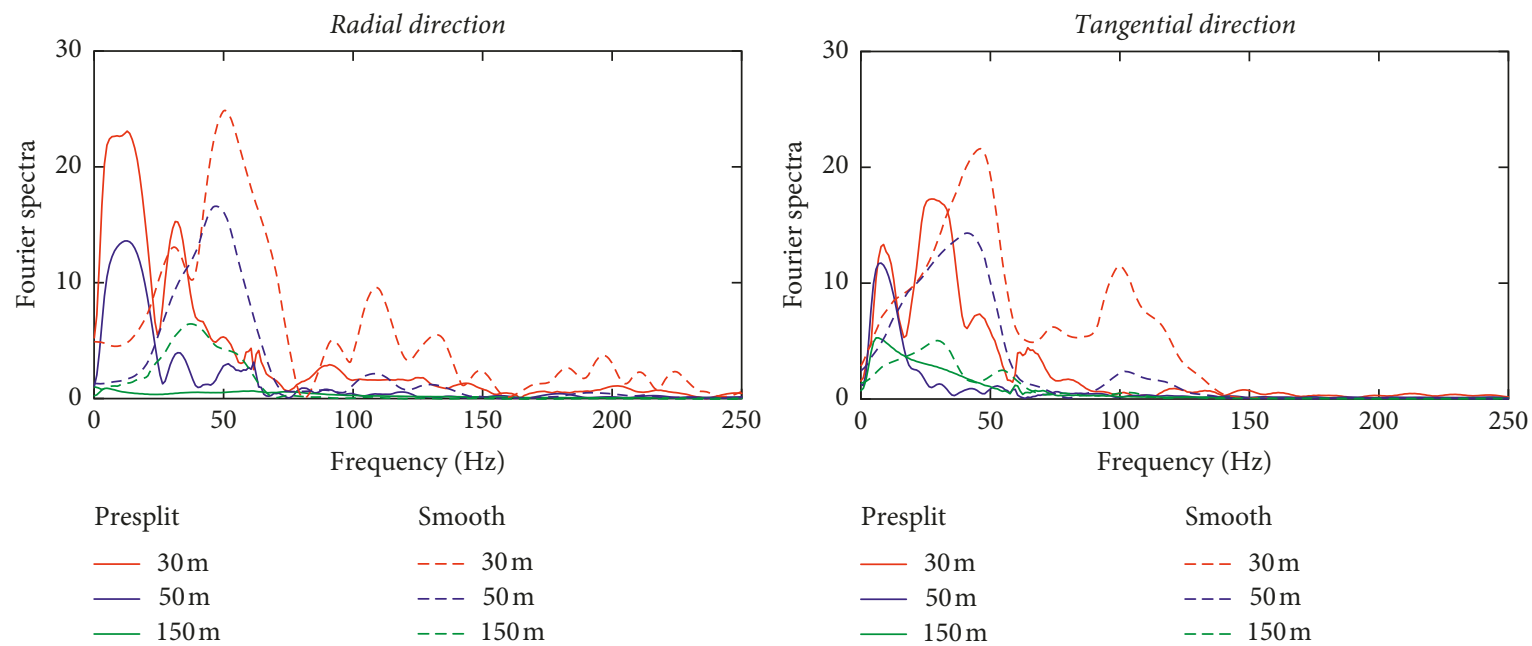

(a)
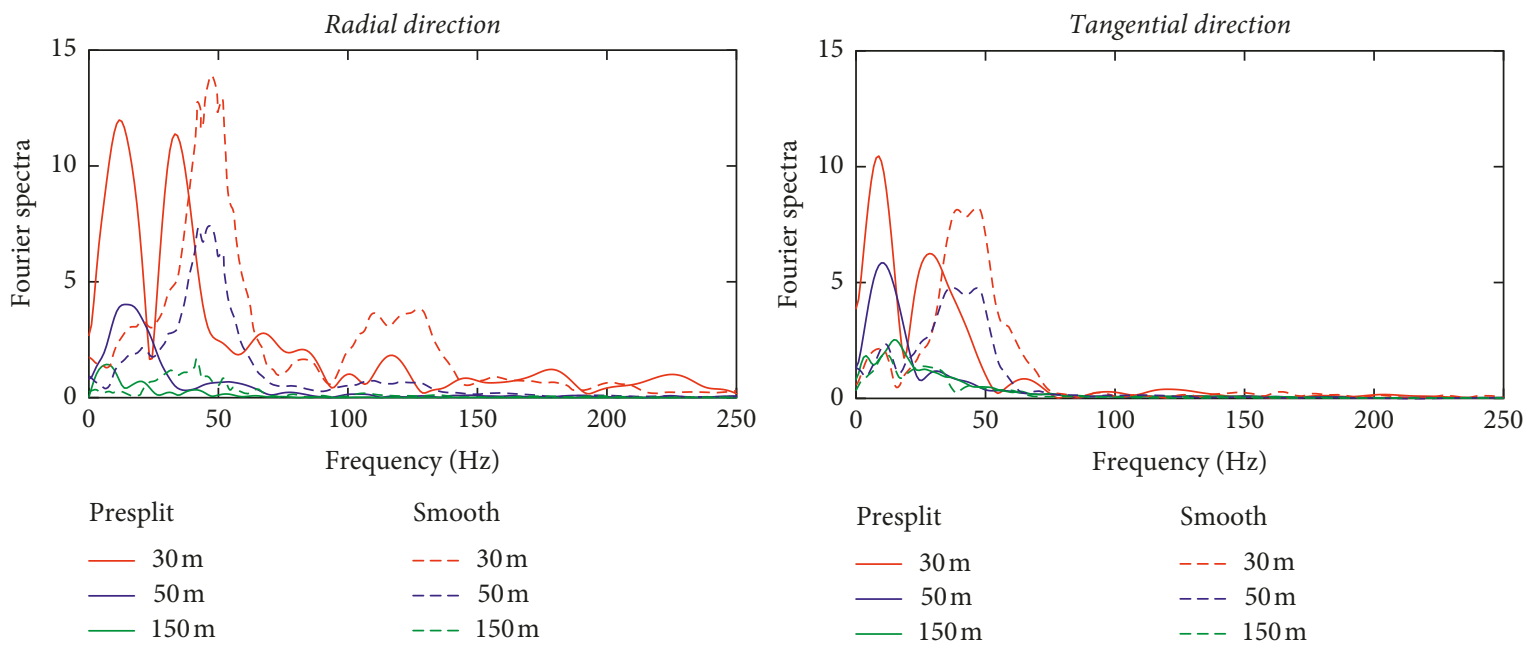

(b)

Figure 6: The frequency spectra of vibration signals from (a) main and (b) peripheral boreholes in the radial and tangential directions based on presplit and smooth blasting.

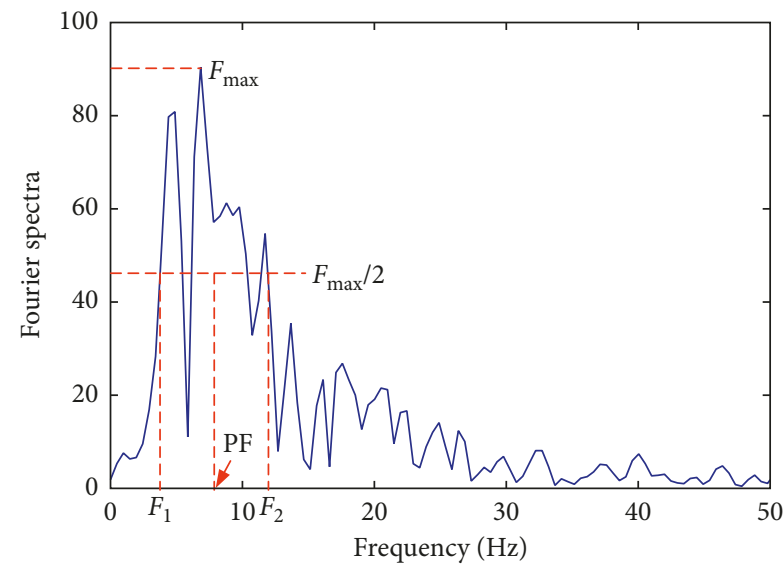

FIgURE 7: Definitions of principal frequency (PF). signal series $h(t)$ is $w_{m}$, bandwidth of $f_{i, j}\left(t_{j}\right)$ is $w_{m} / 2^{i}$. The energy coefficient $E_{i, j}\left(t_{j}\right)$ of every reconstructed signal can be calculated by

$$
E_{i, j}\left(t_{j}\right)=\int\left|f_{i, j}\left(t_{j}\right)\right|^{2} d t
$$

The ratio ED of energy distribution at the $j^{\text {th }}$ frequency band can be expressed by

$$
\mathrm{ED}=\frac{E_{i, j}\left(t_{j}\right)}{\sum_{j=1}^{2^{i}-1} E_{i, j}\left(t_{j}\right)} .
$$

According to equation (5), the percentages of energy distributions at different frequency bands can be obtained. The results of energy distributions for main and peripheral 


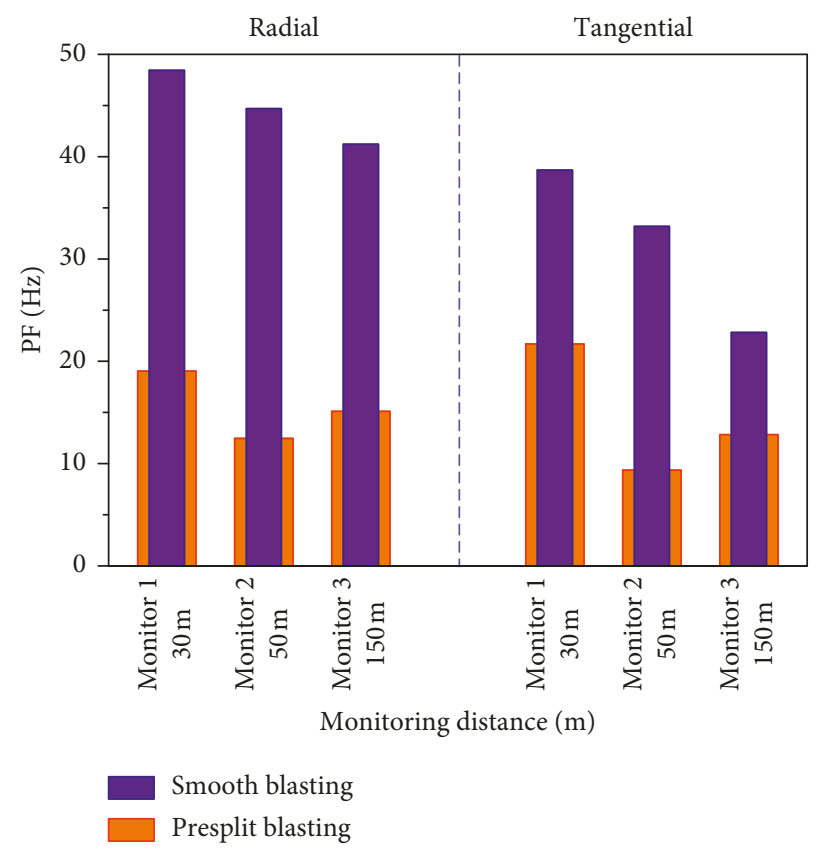

(a)

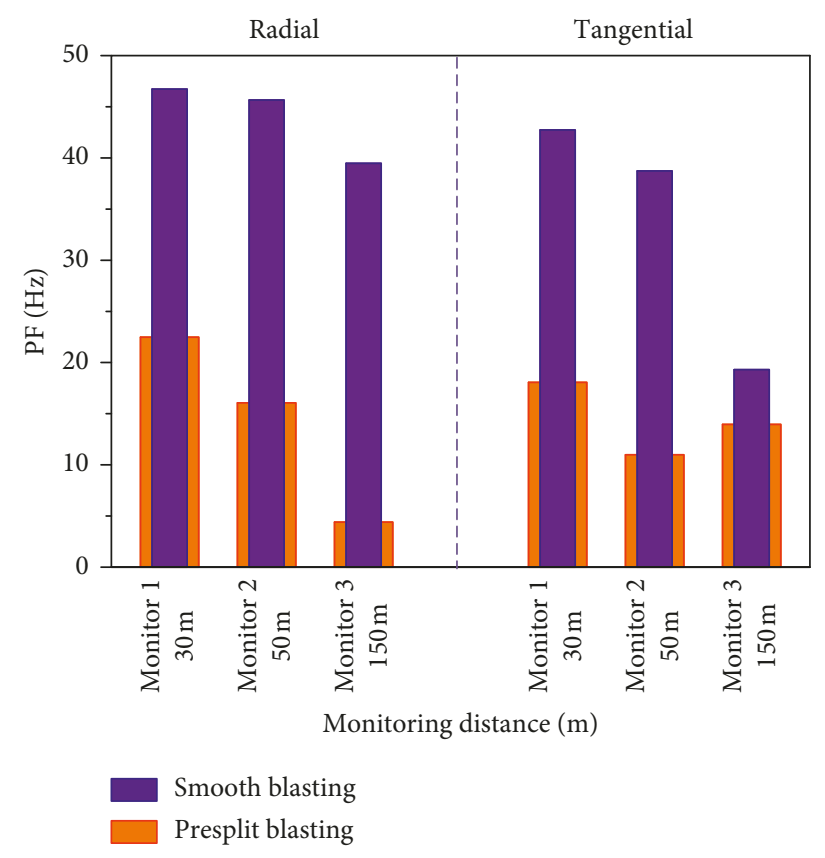

(b)

FIGURE 8: The principal frequencies of vibration signals from (a) main and (b) peripheral boreholes versus monitoring distances based on presplit and smooth blasting.

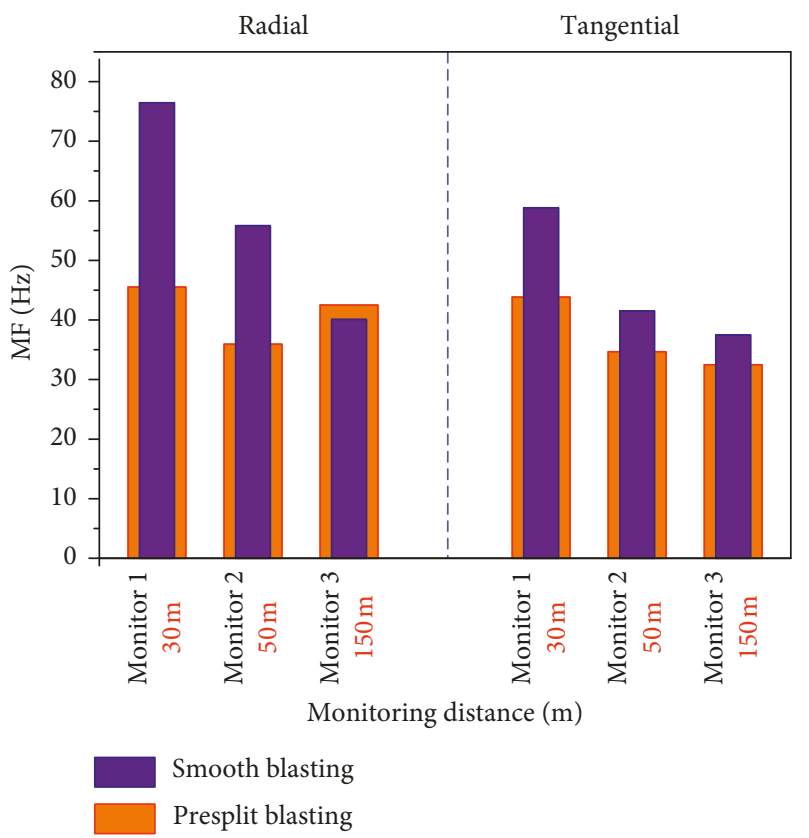

(a)

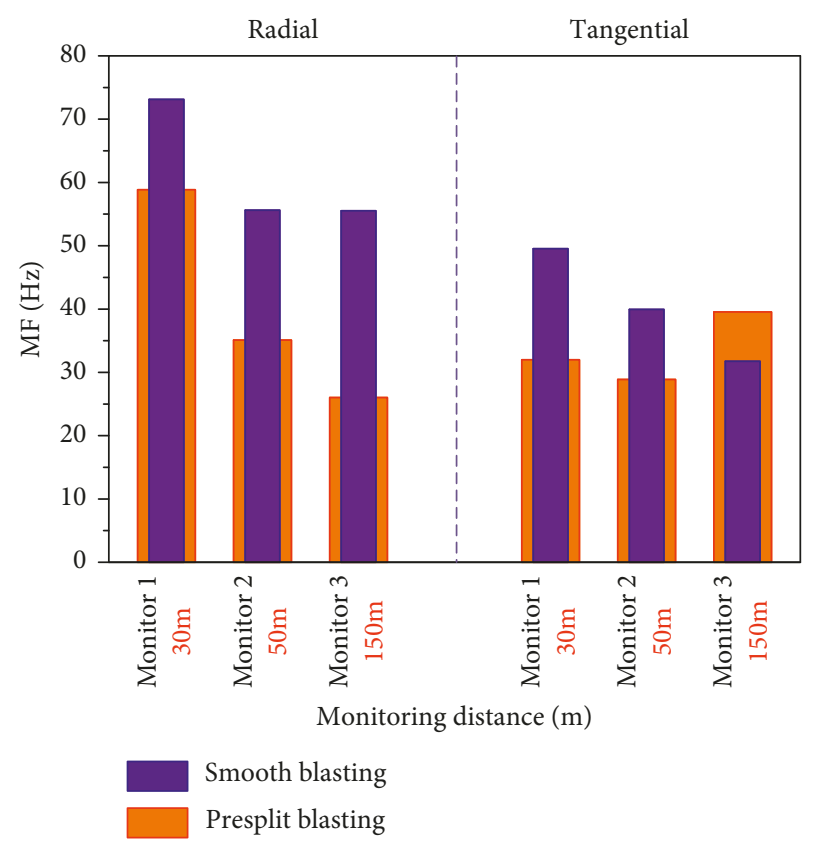

(b)

FIGURE 9: The mean frequencies of vibration signals from (a) main and (b) peripheral boreholes versus monitoring distances based on presplit and smooth blasting.

boreholes are shown in Figures 10 and 11, respectively. It can be seen that at the same monitoring distances and directions, frequency bands of energy distribution based on smooth blasting are more dispersed than that based on presplit blasting, whether main and peripheral boreholes. For instance, for main boreholes (see Figure 10), when the monitoring distance is $30 \mathrm{~m}$ in the radial direction, most of the signal energies based on presplit blasting are distributed 

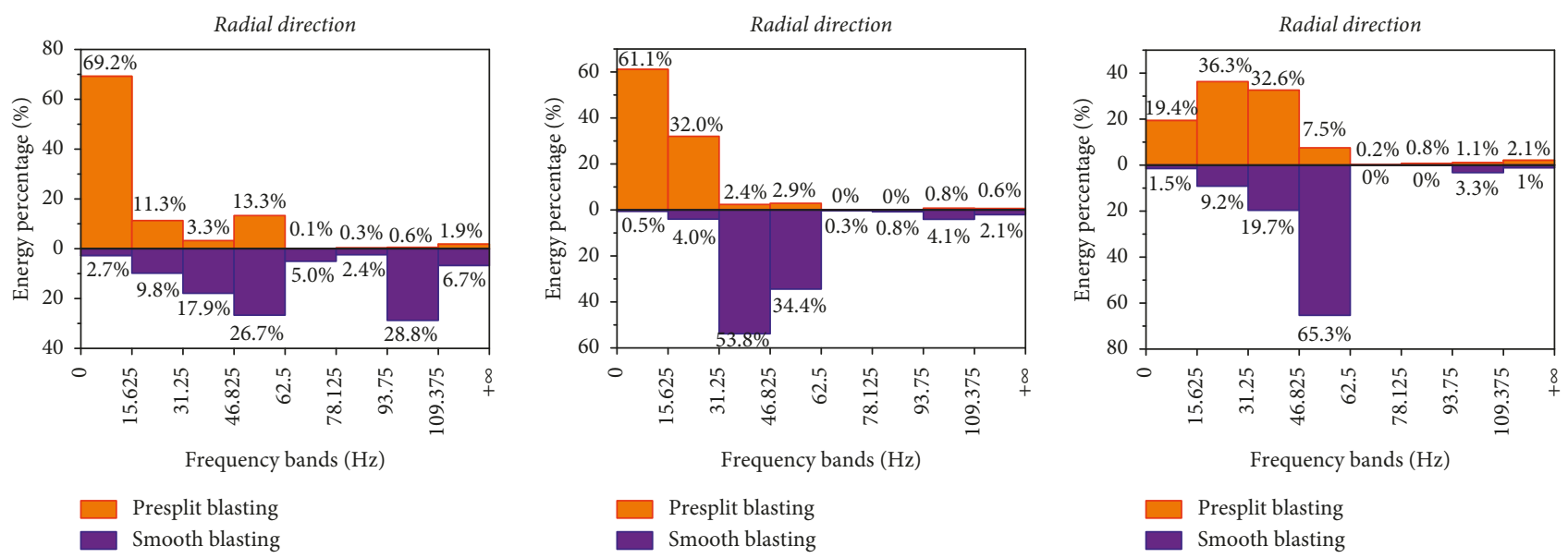

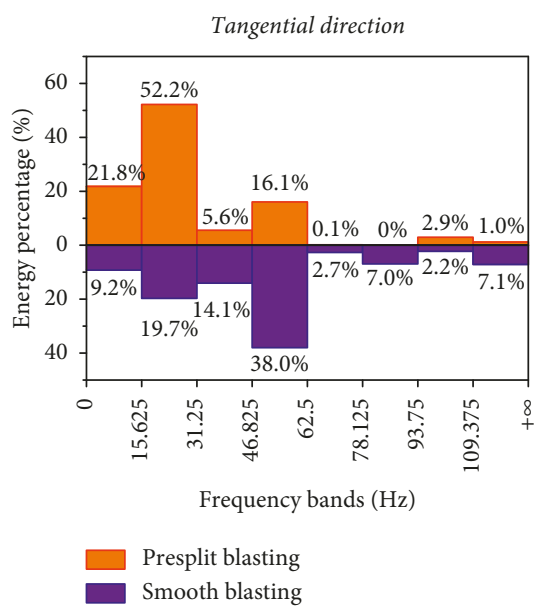

(a)

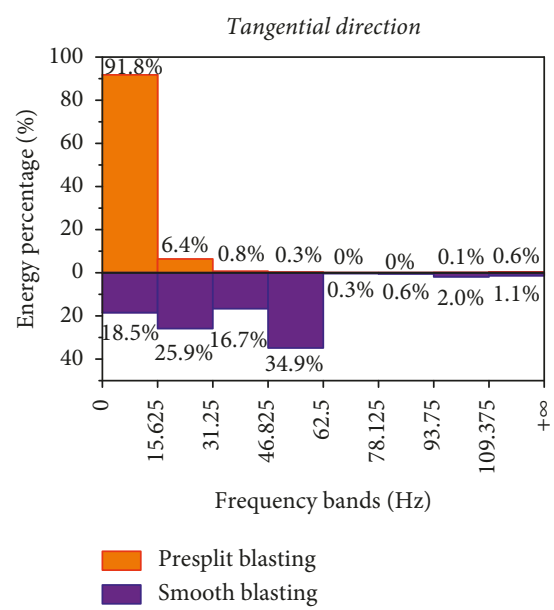

(b)

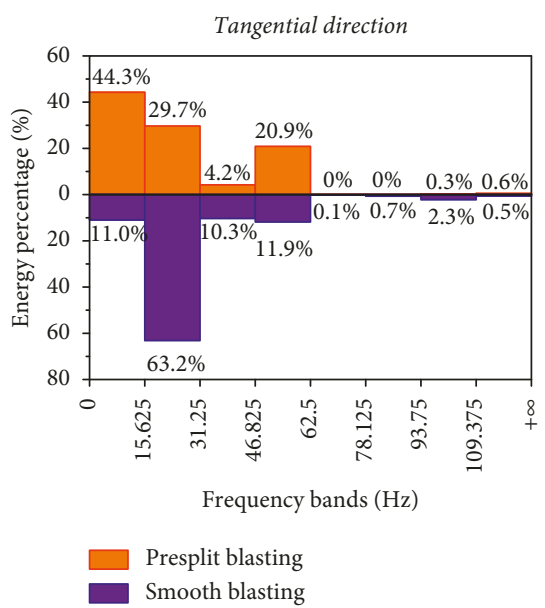

(c)

Figure 10: The percentages of energy distribution from main boreholes in different frequency bands based on smooth and presplit blasting at different monitoring distances. (a) $30 \mathrm{~m}$. (b) $50 \mathrm{~m}$. (c) $150 \mathrm{~m}$.

within $15.625 \mathrm{~Hz}$. However, the signal energies based on smooth blasting are distributed in the frequency bands of 31.25-62.5 Hz and 93.75-109.375 Hz. Meanwhile, it can be found that the frequency bands of energy distribution based on presplit blasting are lower than that based on smooth blasting, whether main or peripheral boreholes. For example, for peripheral boreholes (see Figure 11), at the $50 \mathrm{~m}$ monitoring distance and radial direction, the signal energies based on the presplit blasting are mainly distributed in 15.625-31.25 Hz, but most of the signal energies based on the smooth blasting are distributed in 31.25$62.5 \mathrm{~Hz}$. Besides, when the monitoring distances increase from $30 \mathrm{~m}$ to $50 \mathrm{~m}$, the ratios of signal energies in lowfrequency bands for main boreholes based on the presplit blasting both increase in the radial and tangential directions. The results indicate that the high-frequency components decrease with the increases of monitoring distances. However, when the monitoring distance increases to $150 \mathrm{~m}$, the energy ratios of high frequency bands both increase again in the radial and tangential directions. The results demonstrate that the low-frequency components of the vibration signals are also decreased with the increases of monitoring distances.
3.2. Excavation Results of Rock Wells. Except for the blastinduced vibration characteristics, excavation qualities of rock wells also need to be detected to reveal the differences of presplit and smooth blasting. After the broken rocks are cleared up, the excavation results of two rock wells are obtained and depicted in Figure 12. From the left pictures of Figures 12(a) and 12(b) (obtained by the image processing of well photos), it can be found that some rock bulks are hung on the well wall generated with presplit blasting, but there are no obvious rock bulks on the well wall generated by smooth blasting. From the right pictures of Figures 10(a) and 10(b), it can be seen that the large overbreak volume occurs at the left side of well wall when presplit blasting is applied. However, the actual contour based on smooth blasting is close to the designed contour line. There are two main reasons for the difference of contour qualities generated by two control techniques. On the one hand, there could be the weak connection between the rock mass in the left of well contour for the first experiment using presplit blasting. On the other hand, the presplit boreholes are fired prior to the main boreholes, which causes the explosive in the presplit boreholes to sustain the large resistance force of the inner rock masses, 

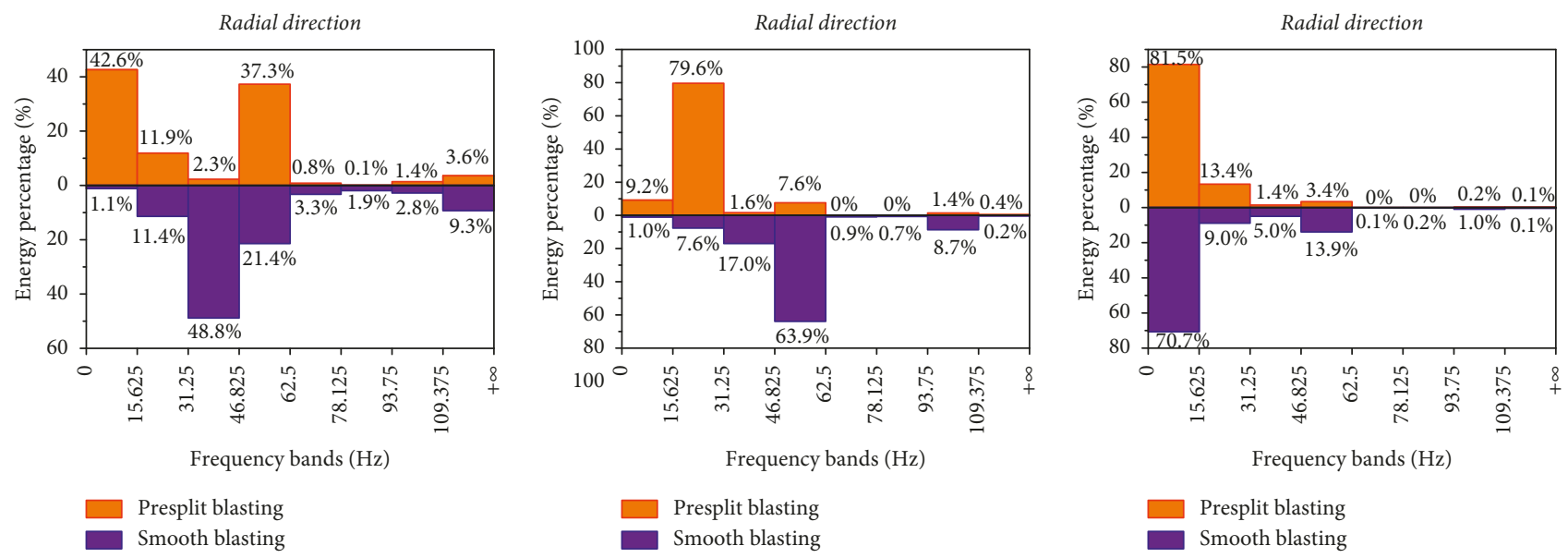

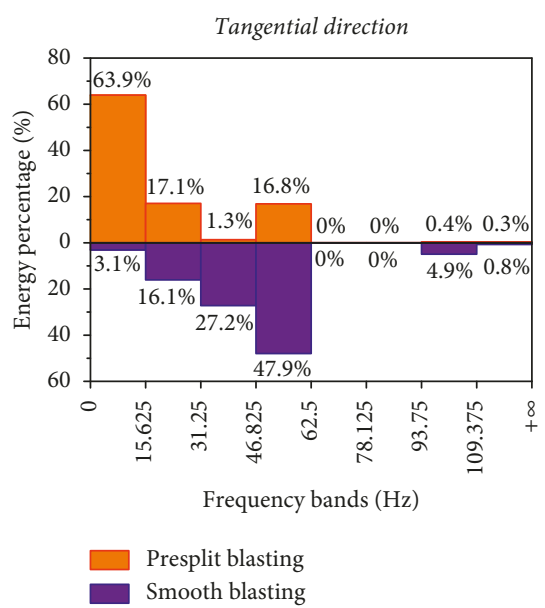

(a)

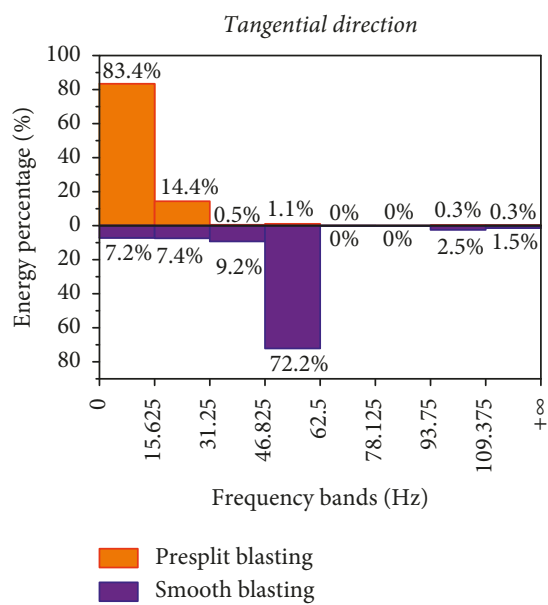

(b)

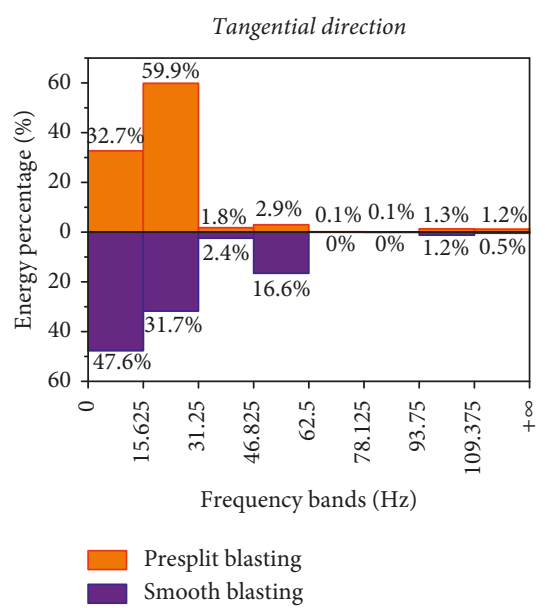

(c)

FIgURE 11: The percentages of energy distribution from peripheral boreholes in different frequency bands based on smooth and presplit blasting at different monitoring distances. (a) $30 \mathrm{~m}$. (b) $50 \mathrm{~m}$. (c) $150 \mathrm{~m}$.

making the more explosion pressure squeezed to the outside of the designed contour. The large explosion pressure cracks the weak connection between the left rock masses of the well contour, forming the overbreak area. However, when charges in the smooth holes are fired, the internal rock has been broken, reducing the resistance force of the inner rock masses, making more explosion pressure squeeze to the center of the rock well. The outside of the well contour suffers less explosion pressure. Hence, the wall well based on smooth blasting is neater than that based on presplit blasting.

To further explore differences of excavation results based on two techniques, the visible depths of five main boreholes and twelve peripheral boreholes are measured. Their results are shown in Figure 13. For the first experiment with the presplit technique, the depths of five main boreholes are $5.8 \mathrm{~m}, 6.8 \mathrm{~m}, 6.5 \mathrm{~m}, 6.3 \mathrm{~m}$, and $6.1 \mathrm{~m}$, respectively. The depths of twelve peripheral holes vary from $1.6 \mathrm{~m}$ to $5.5 \mathrm{~m}$. For the second experiment with the smooth technique, the depths of five main boreholes are $5.2 \mathrm{~m}$, $5.2 \mathrm{~m}, 5.25 \mathrm{~m}, 5.2 \mathrm{~m}$, and $5.25 \mathrm{~m}$, respectively. The depths of twelve peripheral holes vary from $4.2 \mathrm{~m}$ to $4.7 \mathrm{~m}$. It can be found that the average depth of main boreholes with presplit blasting is larger than that with smooth blasting. Meanwhile, the flatness of well bottom with smooth blasting is better than that with presplit blasting. The difference of depth and flatness between two rock wells could be related to the inconsistent geological conditions and the different excavation sequences of two contour techniques. Due to the large excavation range, it is difficult to ensure that the properties of rock masses are consistent in the two experiments, which may influence the consistency of excavation depth and flatness for two wells. In addition, the contour cracks based on the presplit blasting are formed before the main blasting area, but the contour cracks based on smooth blasting are formed after the main blasting area. This situation makes the clamping force of main boreholes based on the presplit blasting decrease. So, the depth of main blasting area with the presplit blasting is larger than that with the smooth blasting. At the same time, in the process of contour crack formation, the peripheral boreholes based on the presplit blasting suffer the larger resistance force of the inner rock masses than that based on smooth boreholes. So, the flatness of rock well based on smooth blasting is better than that based on the presplit blasting. 

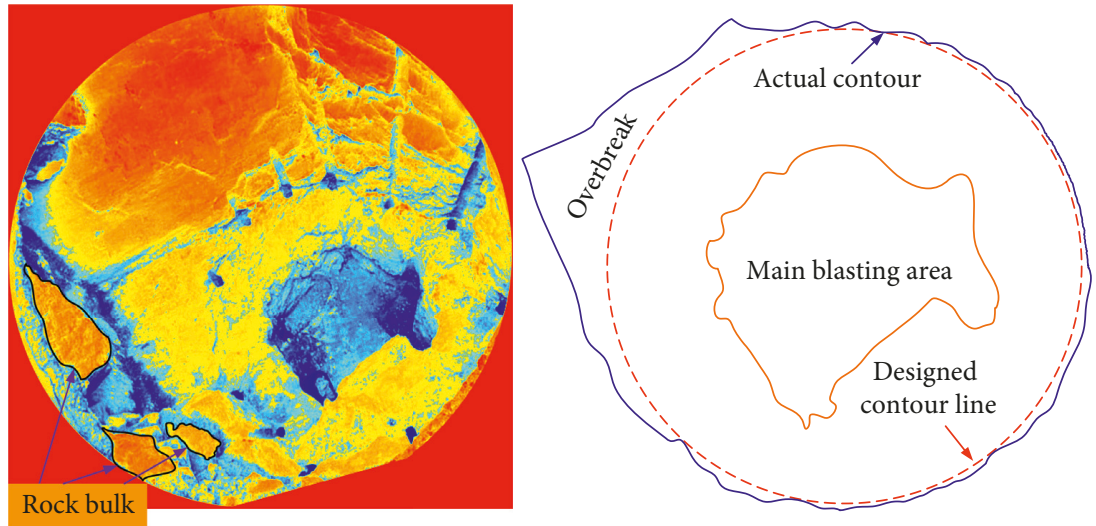

(a)
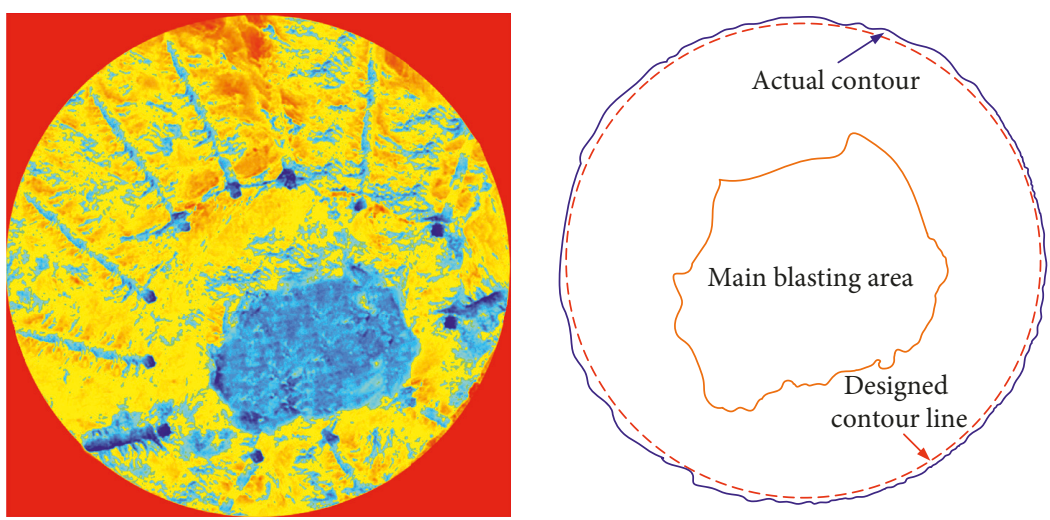

(b)

FiguRE 12: Excavation results of rock wells based on (a) presplit blasting and (b) smooth blasting.

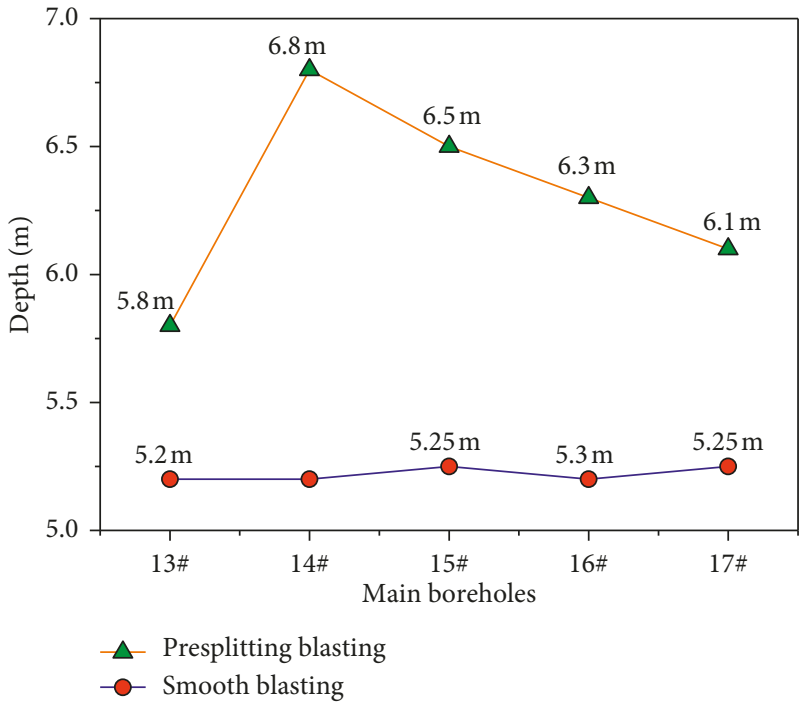

(a)

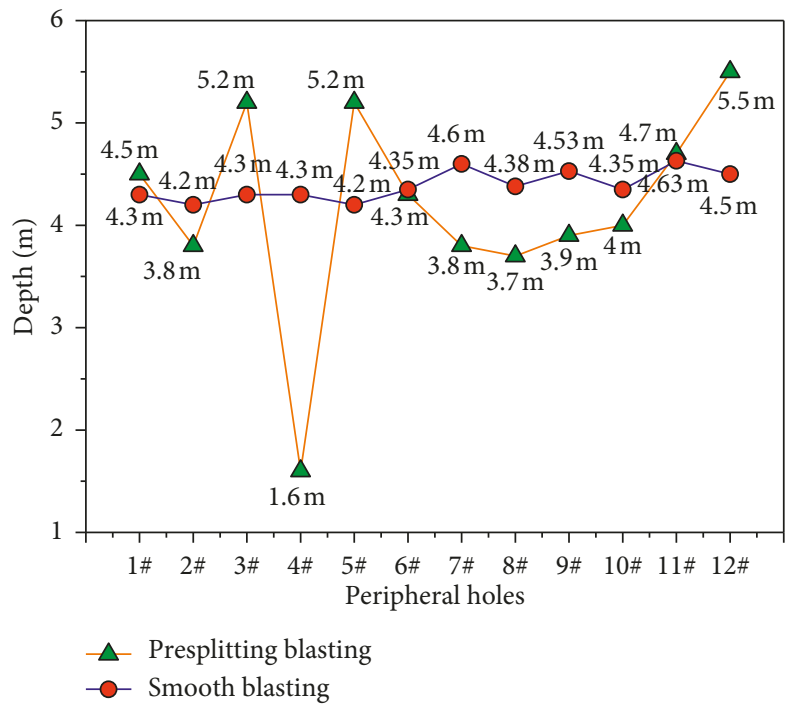

(b)

FIgURE 13: The depths of main and peripheral boreholes generated by two experiments. (a) The depths of five main boreholes. (b) The depths of peripheral holes.

\section{Conclusion}

In this study, the two field experiments for the excavation of rock wells are implemented to reveal the differences of smooth and presplit control techniques. Rock vibration characteristics induced by the two experiments are analyzed by the PPV, frequency, and energy. In addition, The excavation results based on two contour techniques are 
compared from excavation depth and well quality. By this work, the main conclusions can be drawn as follows:

(1) From the analysis results of PPV and frequency, at the same monitoring sites and directions, the PPVs from main boreholes based on smooth blasting are larger than that based on presplit blasting. The ranges of frequency bands based on the smooth blasting are wider than those based on the presplit blasting. The dominant frequencies of vibration signals based on presplit blasting are always smaller than those based on smooth blasting. Moreover, the principle and mean frequencies based on the smooth technique decrease with the increases of distances. However, the principle and mean frequencies based on the presplit technique might firstly decrease and then rise.

(2) Through using the wavelet packet method, distribution bands of signal energies based on smooth blasting are more dispersive than those based on presplit blasting. Meanwhile, the frequency bands of energy distributions based on presplit blasting are lower than that based on smooth blasting. In addition, when the monitoring distances increase to $150 \mathrm{~m}$, the energy ratios of low frequency components for main boreholes based on the presplit blasting decrease obviously. However, those based on the smooth blasting are still large.

(3) Although the geological conditions and rock properties are different for the two experiments, the excavation results still show to some extent that the smooth blasting can obtain the better contour quality and the flatness than the presplit blasting. At the same time, the presplit blasting can obtain the larger well depth than the smooth blasting by the same excavation parameters. Hence, the contour blasting techniques need to be selected flexibly by engineering requirements.

\section{Data Availability}

The data used to support the findings of this study are available from the corresponding author upon request.

\section{Conflicts of Interest}

The authors declare that there are no conflicts of interest regarding the publication of this paper.

\section{Acknowledgments}

The authors are very grateful to the financial contribution and convey their appreciation to the organization for supporting this basic research. The authors also thank the operators and leaders of the test site for their help. This work was supported by the National Basic Research Program of China (2015CB060200), the National Natural Science Foundation of China (41772313 and 51804339), and the Key Research and Development Program of Hunan (2016SK2003).

\section{References}

[1] H. Haoran, L. Wenbo, Y. Peng, C. Ming, and G. Qidong, "A vibration-isolating blast technique with shock-reflection device for dam foundation excavation in complicated geological conditions," Shock and Vibration, vol. 2018, Article ID 8029513, 11 pages, 2018.

[2] X. Qiu, X. Shi, Y. Gou, J. Zhou, H. Chen, and X. Huo, "Shortdelay blasting with single free surface: results of experimental tests," Tunnelling and Underground Space Technology, vol. 74, pp. 119-130, 2018.

[3] H. Chu, X. Yang, S. Li, and W. Liang, "Experimental investigation of the propagation and attenuation rule of blasting vibration wave parameters based on the damage accumulation effect," Shock and Vibration, vol. 2018, Article ID 2493149, 9 pages, 2018.

[4] Z. Zhou, R. Cheng, X. Cai, D. Ma, and C. Jiang, "Discrimination of rock fracture and blast events based on signal complexity and machine learning," Shock and Vibration, vol. 2018, Article ID 9753028, 10 pages, 2018.

[5] Z. Zhou, X. Cai, D. Ma et al., "Water saturation effects on dynamic fracture behavior of sandstone," International Journal of Rock Mechanics and Mining Sciences, vol. 114, pp. 46-61, 2019.

[6] D. Ma, H. Duan, J. Liu, X. Li, and Z. Zhou, "The role of gangue on the mitigation of mining-induced hazards and environmental pollution: an experimental investigation," Science of the Total Environment, vol. 664, pp. 436-448, 2019.

[7] X. Xia, H. Li, Y. Liu, and C. Yu, "A case study on the cavity effect of a water tunnel on the ground vibrations induced by excavating blasts," Tunnelling and Underground Space Technology, vol. 71, pp. 292-297, 2018.

[8] H. K. Verma, N. K. Samadhiya, M. Singh, R. K. Goel, and P. K. Singh, "Blast induced rock mass damage around tunnels," Tunnelling and Underground Space Technology, vol. 71, pp. 149-158, 2018.

[9] D. Saiang and E. Nordlund, "Numerical analyses of the influence of blast-induced damaged rock around shallow tunnels in brittle rock," Rock Mechanics and Rock Engineering, vol. 42, no. 3, pp. 421-448, 2009.

[10] F. Feng, X. Li, J. Rostami, and D. Li, "Modeling hard rock failure induced by structural planes around deep circular tunnels," Engineering Fracture Mechanics, vol. 205, pp. 152174, 2019.

[11] P. K. Singh, M. P. Roy, and R. K. Paswan, "Controlled blasting for long term stability of pit-walls," International Journal of Rock Mechanics and Mining Sciences, vol. 70, pp. 388-399, 2014.

[12] F. Wang, S. Tu, Y. Yuan, Y. Feng, F. Chen, and H. Tu, "Deephole pre-split blasting mechanism and its application for controlled roof caving in shallow depth seams," International Journal of Rock Mechanics and Mining Sciences, vol. 64, pp. 112-121, 2013.

[13] Z. Zhang, N. Zhang, H. Shimada, T. Sasaoka, and S. Wahyudi, "Optimization of hard roof structure over retained goaf-side gateroad by pre-split blasting technology," International Journal of Rock Mechanics and Mining Sciences, vol. 100, pp. 330-337, 2017.

[14] Z. Dingxiang, Theory and Technology of Rock Excavation for Civil Engineering, Springer, Singapore, 2017.

[15] R. N. Gupta, M. M. Singh, and B. Singh, "Application of presplitting and smooth blasting for excavation of a large power house cavern," in Proceedings of the 28th US Symposium on Rock Mechanics (USRMS), American Rock Mechanics Association, Tucson, AZ, USA, June-July 1987. 
[16] S. Zare and A. Bruland, "Comparison of tunnel blast design models," Tunnelling and Underground Space Technology, vol. 21, no. 5, pp. 533-541, 2006.

[17] S. K. Mandal, M. M. Singh, and S. Dasgupta, "Theoretical concept to understand plan and design smooth blasting pattern," Geotechnical and Geological Engineering, vol. 26, no. 4, pp. 399-416, 2008.

[18] L. Ma, K. Li, S. Xiao, X. Ding, and S. Chinyanta, "Research on effects of blast casting vibration and vibration absorption of presplitting blasting in open cast mine," Shock and Vibration, vol. 2016, Article ID 4091732, 9 pages, 2016.

[19] X. P. Li, J. H. Huang, Y. Luo, and P. P. Chen, "A study of smooth wall blasting fracture mechanisms using the timing sequence control method," International Journal of Rock Mechanics and Mining Sciences, vol. 92, pp. 1-8, 2017.

[20] K. Liu and B. Liu, "Optimization of smooth blasting parameters for mountain tunnel construction with specified control indices based on a GA and ISVR coupling algorithm," Tunnelling and Underground Space Technology, vol. 70, pp. 363-374, 2017.

[21] W. Lu, M. Chen, X. Geng, D. Shu, and C. Zhou, "A study of excavation sequence and contour blasting method for underground powerhouses of hydropower stations," Tunnelling and Underground Space Technology, vol. 29, pp. 31-39, 2012.

[22] Y. Hu, W. Lu, M. Chen, P. Yan, and J. Yang, "Comparison of blast-induced damage between presplit and smooth blasting of high rock slope," Rock mechanics and rock engineering, vol. 47, no. 4, pp. 1307-1320, 2014.

[23] Y. Hu, W. Lu, X. Wu, M. Liu, and P. Li, "Numerical and experimental investigation of blasting damage control of a high rock slope in a deep valley," Engineering Geology, vol. 237, pp. 12-20, 2018.

[24] A. K. Verma and T. N. Singh, "Intelligent systems for ground vibration measurement: a comparative study," Engineering with Computers, vol. 27, no. 3, pp. 225-233, 2011.

[25] S. Dauji, "New approach for identification of suitable vibration attenuation relationship for underground blasts," Engineering Journal, vol. 22, no. 4, pp. 147-159, 2018.

[26] V. F. N. Torres, L. G. C. Silveira, P. F. T. Lopes, and H. M. de Lima, "Assessing and controlling of bench blastinginduced vibrations to minimize impacts to a neighboring community," Journal of Cleaner Production, vol. 187, pp. 514-524, 2018.

[27] Y. Qiang, Y. Xingguo, and L. Hongtao, "A method for evaluating the comfort during blasting vibration based on energy absorbing principle," Journal of Vibration and Control, vol. 24, no. 11, pp. 2301-2311, 2018.

[28] J. Yang, W. Lu, Q. Jiang, C. Yao, S. Jiang, and L. Tian, “A study on the vibration frequency of blasting excavation in highly stressed rock masses," Rock Mechanics and Rock Engineering, vol. 49, no. 7, pp. 2825-2843, 2016.

[29] C. Wu, Y. Lu, H. Hao, W. K. Lim, Y. Zhou, and C. C. Seah, "Characterisation of underground blast-induced ground motions from large-scale field tests," Shock Waves, vol. 13, no. 3, pp. 237-252, 2003.

[30] J. H. Yang, W. B. Lu, Q. H. Jiang, C. Yao, and C. B. Zhou, "Frequency comparison of blast-induced vibration per delay for the full-face millisecond delay blasting in underground opening excavation," Tunnelling and Underground Space Technology, vol. 51, pp. 189-201, 2016.

[31] T.-H. Ling, X.-B. Li, T.-G. Dai, and Z.-B. Peng, "Features of energy distribution for blast vibration signals based on wavelet packet decomposition," Journal of Central South University of Technology, vol. 12, no. 1, pp. 135-140, 2005. 


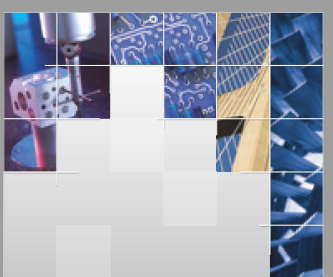

\section{Enfincering}
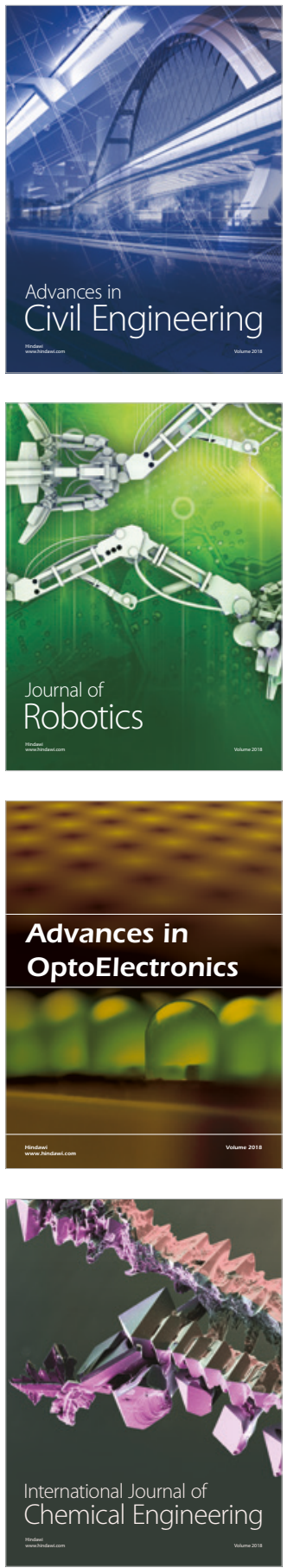

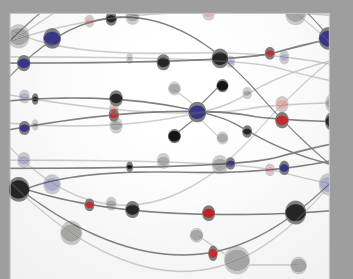

\section{Rotating \\ Machinery}

The Scientific World Journal

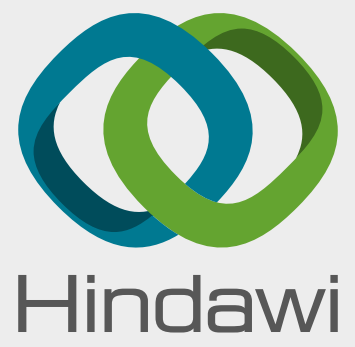

Submit your manuscripts at

www.hindawi.com
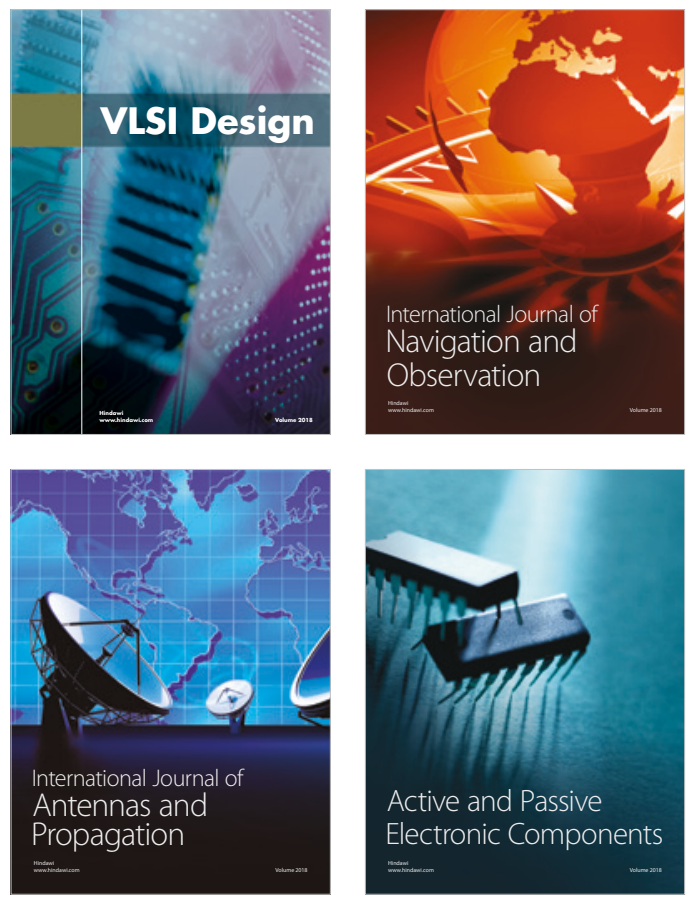
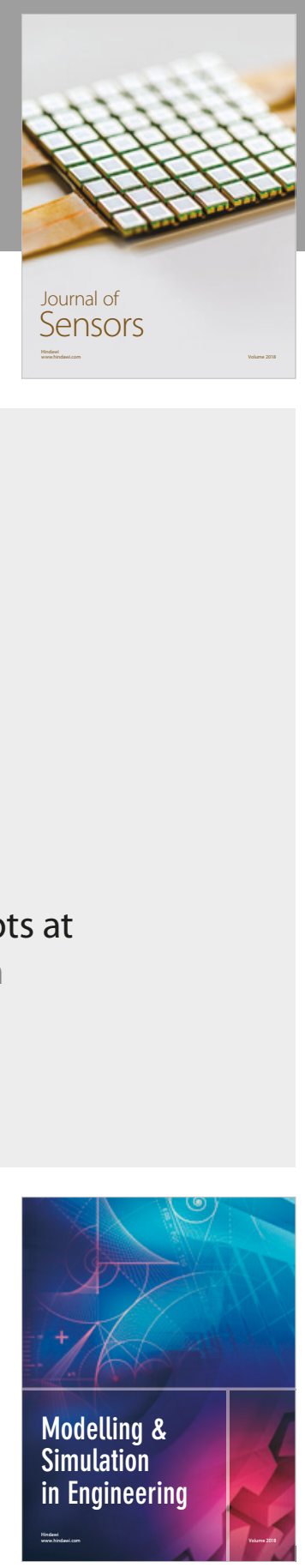

\section{Advances \\ Multimedia}
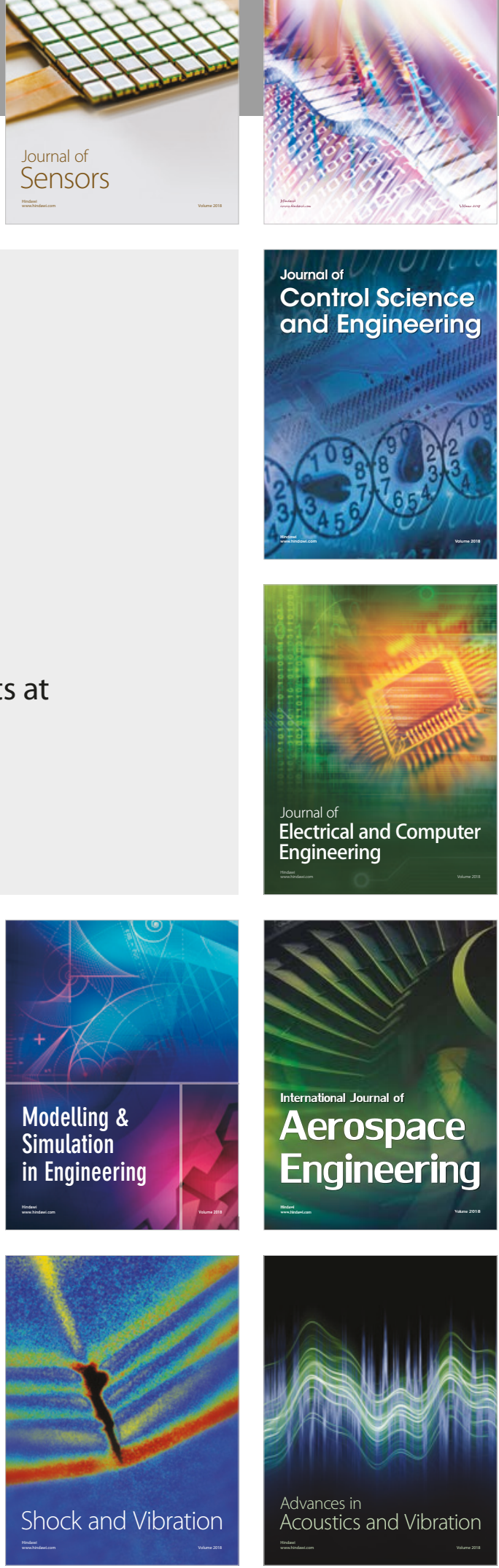